\title{
Mnt, a novel Max-interacting protein is coexpressed with Myc in proliferating cells and mediates repression at Myc binding sites
}

\author{
Peter J. Hurlin, Christophe Quéva, and Robert N. Eisenman ${ }^{1}$ \\ Division of Basic Sciences, Fred Hutchinson Cancer Research Center, Seattle, Washington 98104 USA
}

\begin{abstract}
The small constitutively expressed bHLHZip protein Max is known to form sequence-specific DNA binding heterodimers with members of both the Myc and Mad families of bHLHZip proteins. Myc:Max complexes activate transcription, promote proliferation, and block terminal differentiation. In contrast, Mad:Max heterodimers act as transcriptional repressors, have an antiproliferative effect, and are induced upon differentiation in a wide variety of cell types. We have identified a novel bHLHZip Max-binding protein, Mnt, which belongs to neither the Myc nor the Mad families and which is coexpressed with Myc in a number of proliferating cell types. Mnt:Max heterodimers act as transcriptional repressors and efficiently suppress Myc-dependent activation from a promoter containing proximal CACGTG sites. Transcription repression by Mnt maps to a 13-amino-acid amino-terminal region related to the Sin3 interaction domain (SID) of Mad proteins. We show that this region of $M n t$ mediates interaction with $\mathrm{mSin} 3$ corepressor proteins and that its deletion converts $\mathrm{Mnt}$ from a repressor to an activator. Furthermore, wild-type Mnt suppresses Myc+Ras cotransformation of primary cells, whereas Mnt containing a SID deletion cooperates with Ras in the absence of Myc to transform cells. This suggests that Mnt and Myc regulate an overlapping set of target genes in vivo. When mnt is expressed as a transgene under control of the $\beta$-actin promoter in mice the transgenic embryos exhibit a delay in development and die during mid-gestation, when c- and $\mathrm{N}$-Myc functions are critical. We propose that Mnt:Max:Sin3 complexes normally function to restrict Myc:Max activities associated with cell proliferation.
\end{abstract}

[Key Words: Max; Myc; Mnt; mSin3; repression; transformation; transgenic mouse]

Received September 25, 1996; accepted in revised form October 29, 1996.

The myc proto-oncogene family encodes transcriptional regulatory proteins that are thought to govern cell cycle entry, progression, and differentiation (Lüscher and Eisenman 1990; DePinho et al. 1991; Marcu et al. 1992; Henriksson and Lüscher 1996). Expression of myc genes is under complex control at both the transcriptional and post-transcriptional levels, suggesting that the temporal pattern of myc expression, the level of Myc protein, or both are important (Spencer and Groudine 1991). That regulation of the abundance of Myc protein in cells is critical is supported by the results of both gene deletion and overexpression studies. Whereas homozygous deletion of either c-myc or N-myc results in embryonic lethality (Stanton et al. 1992; Charron et al. 1992; Davis et al. 1993; Moens et al. 1993; Sawai et al. 1993), overexpression of Myc proteins in transgenic animals and cultured cells can inhibit differentiation, induce neoplastic

${ }^{1}$ Corresponding author.

E-MAIL eisenman@fred.fhcrc.org; FAX (206) 667-6522. transformation, and under certain conditions initiate apoptosis (Coppola and Cole 1986; Askew et al. 1991; Evan et al. 1992; for review, see Cory and Adams 1988). Furthermore, chromosomal translocation, insertional mutagenesis, and gene amplification occurring at myc loci in a broad range of naturally occurring tumors underscores the importance of maintaining proper regulation of Myc protein levels.

In addition to mechanisms regulating the abundance of Myc proteins in cells, the biochemical and biological activities of Myc are dependent on specific protein-protein interactions mediated by the Myc basic helix-loophelix-leucine zipper (bHLHZip) domain. Of major importance is the association between Myc and its dimerization partner Max. Max is a small, ubiquitously expressed bHLHZip protein required for the DNA binding, transcription activation, transformation, and apoptosis-inducing properties of Myc proteins (Blackwood and Eisenman 1991; Prendergast et al. 1991; Amati et al. 1992; Evan et al. 1992; Kretzner et al. 1992; Amati et al. 
1993a,b; Amin et al. 1993; Gu et al. 1993; Mukherjee et al. 1992). Max also heterodimerizes with a second group of bHLHZip proteins, the Mad family (Mad1, Mxi1, Mad3, Mad4). Both Mad:Max and Myc:Max heterodimers recognize common E-box binding sites in vitro, but, whereas Myc:Max activates, Mad:Max represses transcription at artificial promoters containing these sites (Ayer et al. 1993; Zervos et al. 1993; Hurlin et al. 1995b). Repression by Mad:Max appears to be mediated through the further association of $\mathrm{Mad}$ with $\mathrm{mSin} 3 \mathrm{~A}$ and $\mathrm{B}$, mammalian homologs of the Saccharomyces cerevisiae global corepressor SIN3 (Ayer et al. 1995; Hurlin et al. 1995b; Schreiber-Agus et al. 1995; Kastan et al. 1996). There is also evidence that Myc may act to repress genes through binding to a subset of initiator sequences, although it is unclear whether this activity is dependent on Max (Roy et al. 1993; Li et al. 1994).

Because Max is a highly stable protein expressed at nearly constant levels during differentiation or cell cycle entry it is thought that the formation of active heterocomplexes is dependent on expression of Max's shortlived partners: Myc and Mad (Berberich et al. 1992; Blackwood et al. 1992b; Littlewood et al. 1992; Ayer and Eisenman 1993; Ayer et al. 1993). Interestingly, the expression of Myc and Mad is inversely regulated during transitions from proliferation to differentiation (Ayer and Eisenman 1993; Hurlin et al. 1995a). During differentiation of myeloid cells and keratinocytes, c-Myc protein is down-regulated, whereas Madl is induced, and a switch from Myc:Max to Mad:Max is observed (Ayer and Eisenman 1993; Hurlin et al. 1994, 1995a). Similar heterocomplex switching is also likely to occur in other cell types where Myc and Mad proteins are differentially regulated. Indeed, in many tissues myc and mad family RNAs exhibit contrasting patterns of expression with c-myc being expressed primarily in proliferating cell compartments, and different members of the mad family being expressed primarily in cells undergoing differentiation (Hurlin et al. 1995a,b; Västrik et al. 1995; C. Quéva, P.J. Hurlin, and R.H. Eisenman, unpubl.). Because Myc: Max complexes activate transcription and Mad:Max complexes repress transcription at promoter-proximal Ebox sites in transient transfection assays, the switch from Myc to Mad expression has been postulated to be part of a general regulatory pathway controlling cessation of proliferation associated with terminal differentiation. In support of this notion, recent transfection studies have shown that overexpression of Mad proteins can inhibit cell cycle progression (Chen et al. 1995; Roussel et al. 1996) and suppress Myc-dependent transformation of cells (Lahoz et al. 1994; Koskinen et al. 1995; Hurlin et al. 1995b).

The ability of Mad proteins to affect Myc functions in transfected cells predicts that endogenous Max interactors are likely to exert a powerful influence on Myc activities if present in the same cells. In this paper, we describe a novel Max-interacting protein, Mnt, that represses transcription at Myc:Max E-box sites and that is coexpressed with Myc in many proliferating cell types.
Our results suggest that Mnt:Max complexes play a role in regulating Myc activities and cell proliferation.

\section{Results}

\section{Identification of $\mathrm{Mnt}$}

To identify new proteins that interact with Max a yeast two-hybrid screen was performed using cDNA libraries prepared from day 9.5 and 10.5 mouse embryos (see Vojtek et al. 1993; Hollenberg et al. 1995). Full-length Max9 was employed as "bait" as described previously (Hurlin et al. 1995b). In this screen, each of the known Max-interacting proteins, c-, N- and L-Myc, Mad, and Mxil, and four previously unidentified bHLHZip proteins were isolated. The latter included two proteins that, by virtue of high overall sequence homology, were considered to be members of the Mad family and designated Mad3 and Mad4 as reported previously (Hurlin et al. 1995b). Here we describe Mnt, one of the other two novel Max-interactor proteins identified.

From the yeast two-hybrid screen, two independent, overlapping cDNA fragments (mnt clones 13 and 18) were obtained that encoded a bHLHZip region and limited $3^{\prime}$ flanking sequence. Data-base comparisons showed that the Mnt bHLHZip region is most similar to $\operatorname{Max}(58 \%)$, but also related to the other known Max interactors, the Myc and Mad family proteins (Fig. 1A). Because the bHLHZip region of Mnt is most related to Max, we tested whether Mnt interacts with itself and with Myc, Max, and Mad proteins. The Mnt bHLHZip region fused to GST was incubated with in vitro translated, $\left[{ }^{35} \mathrm{~S}\right] \mathrm{m}$ thionine labeled VP16 fusion proteins recovered from the two-hybrid screen, washed, and the bound proteins released and analyzed by SDS-PAGE. The results, shown in Figure 1B, indicate that the Mnt bHLHZip region forms heterocomplexes only with Max, but is also capable of forming homodimers.

To isolate a full-length mnt cDNA, a clone recovered from the two-hybrid analysis was used to screen a murine brain cDNA library. A 4565-nucleotide mnt cDNA was recovered that contained an ATG codon in good context for translation initiation (Kozak 1989) with multiple upstream termination codons (Fig. 2A). Conceptual translation of the mnt cDNA revealed an open reading frame of 591 amino acids (Fig. 2A). In vitro translation of the mnt cDNA followed by SDS-PAGE analysis showed a protein that migrated at $\sim 72 \mathrm{kD}$.

In addition to the bHLHZip region, Mnt contains several regions extremely rich in proline residues (Fig. 2A and $B$ ) with polyproline stretches and multiple repeats of the sequence pro-ala/leu-pro. The proline-rich structure of these regions resembles the activation domains of several different classes of transcription factors including Box I of the c-Myc activation domain (amino acids 4364). These regions of $\mathrm{Mnt}$ also contain many consensus SH3-binding motifs. Mnt also has a predicted coiled-coil $\alpha$-helix structure [Coils program, Swiss Institute for Experimental Cancer Research (ISREC)] at its amino terminus and histidine-rich regions near its carboxyl terminus. 
Hurlin et al.

A

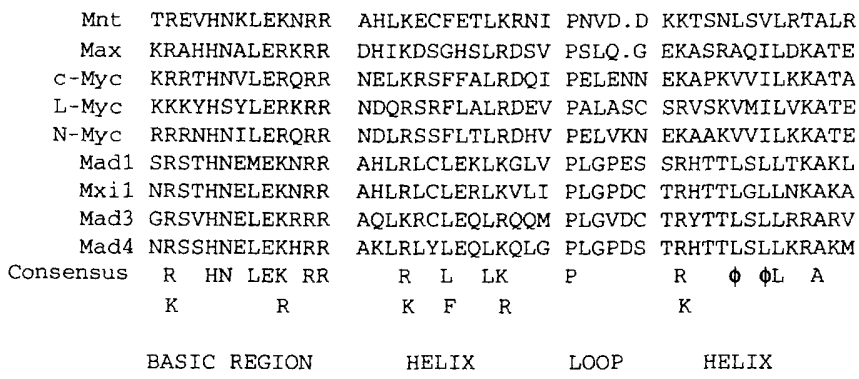

\begin{tabular}{|c|c|c|}
\hline Mnt & Y IQSLKRKEKEYEHEMEPLAREKIATQQRLAELKHELSQW & \\
\hline $\operatorname{Max}$ & IQYMRRKNHTHQQDIDDLKRQNALLEQQVRALEKARSSE & \\
\hline$c-\mathrm{Myc}$ & ILSVQAEEQKL I SEEDLLRKRREQLKHKLEQLRNSCA & \\
\hline $\mathrm{N}-\mathrm{Myc}$ & YVHALQANEHQLLLEKEKLQARQQQLLKKIEHARTC & \\
\hline L-Myc & YLHELAEAEERMATEKRQLECQRRQLQKRIEYLSSY & \\
\hline Mad1 & HIKKLEDCDRKAVHQIDQLQREQRHLKRQLEKLGIERIR & \\
\hline Mxil & HIKKLEEAERKSQHQLENLEREQRFLKWRLEQLQGPQEME & \\
\hline Mad3 & HIQKLEEQEQQARRLKEKLRSKQQSLQQQLEQLQGLPGAR & \\
\hline & HIKKLEEQDRRALSIKEQLQREHRFLKRRLEQLSVQSVER & \\
\hline & L $\quad L$ & \\
\hline
\end{tabular}

Figure 1. Mnt has a Myc-like bHLHZip domain and interacts with Max. (A) An alignment of the bHLHZip domain of Mnt with Max and other Max-interacting proteins. The consensus amino acids of the bHLHZip domain are indicated below. $|B|$ Ten microliters of the in vitro translated VP16 fusion proteins (recovered from the yeast two-hybrid screen) shown in the left panel $\{1 \mu l\}$ were incubated with GST-Mnt-bHLHZip (containing only the Mnt-bHLHZip domain) in the presence of glutathione-Sepharose beads. Beads were washed three times with LS buffer and bound proteins eluted and analyzed by SDS-PAGE and autoradiography.

LEUCINE ZIPPER

B

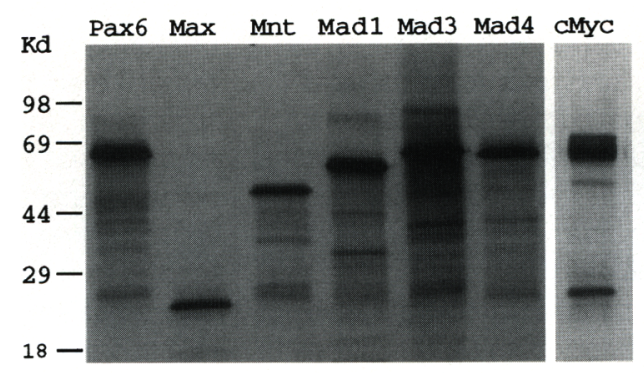

\section{Mnt:Max heterodimers bind CACGTG and repress transcription}

Basic region residues engaged in specific nucleotide contacts have been deduced from the crystal structure of Max homodimers bound to CACGTG (Ferré-D'Amaré et al. 1993). Several of these contact residues are found in equivalent positions in the Mnt basic region, suggesting that Mnt may also interact with E-box sequences. To determine whether Mnt binds to the consensus Myc:Max and Max:Max E-box binding site, CACGTG (Blackwell et al. 1990), electrophoretic mobility shift assays (EMSAs) were performed using the full-length Mnt protein fused to GST. When GST-Mnt was combined with Max and analyzed for binding to an oligonucleotide containing the CACGTG binding site (CM1), a Max homodimer shift was observed along with a second, slower migrating, complex (Fig. 3A). The slower migrating band, but not the Max:Max band, was supershifted and par- tially disrupted in the presence of anti-Mnt serum, but not preimmune serum (see below and Materials and Methods for preparation and characterization of the antibodies). Max antiserum supershifted both the faster migrating (Max:Max) and the slower migrating complexes. These results indicate that the slower migrating band contains Mnt:Max heterocomplexes. Interestingly, the full-length $\mathrm{Mnt}$ protein failed to bind CACGTG in the absence of Max, even though interaction assays indicated that it can form homodimers (see Fig. 1B). We have also employed EMSAs to examine the relative binding activities of Myc and Mnt for Max and for DNA. Constant amounts of Max and either GST-C176Myc (containing the carboxyterminal 176 amino acids of c-Myc) or GST-Mnt were incubated with the CMl oligo in the presence of increasing amounts of GST-Mnt or GSTC176Myc, respectively (Fig. 3B). In both situations a similar degree of competition was observed between approximately equivalent amounts of Myc and Mnt for for- 
A

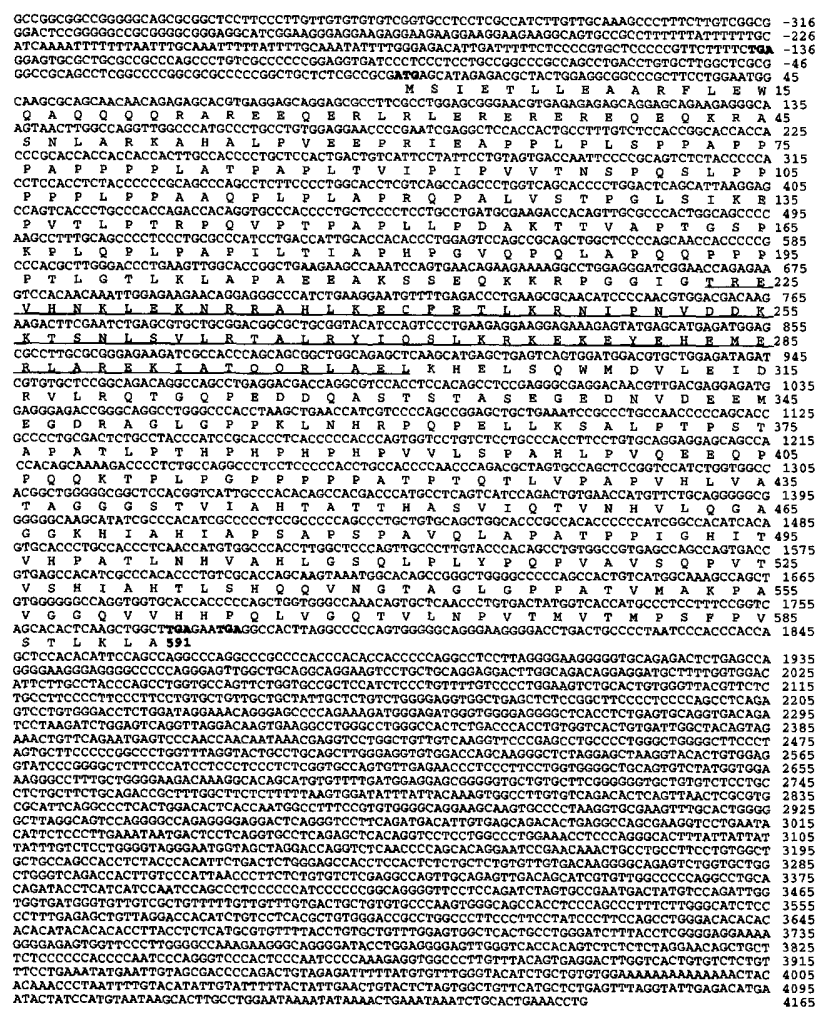

B

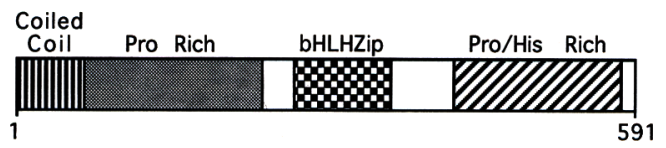

Figure 2. The mnt cDNA and protein. $\{A \mid$ The 4565 -bp murine $m n t$ cDNA (GenBank accession no. U77356) and its conceptual translation. The bHLHZip domain is underlined, and termination codons upstream of the putative start methionine and at the end of the open reading frame are indicated in bold. Nucleotide number one is the A of the start ATG codon (also in bold). Polyadenylation followed the last nucleotide shown. (B) Outline of the organization of the 591-amino-acid Mnt protein.

mation of DNA binding heterodimers with Max (Fig. 3B). These results indicate that Mnt:Max complexes are capable of binding the preferred Myc-Max binding sequence, and that Myc and Mnt bind Max with similar affinities.

To address the potential transcriptional activity of Mnt we transiently transfected 293 cells with expression vectors and the plasmid pGL2M4, containing the luciferase reporter gene linked to a minimal SV40 promoter with a proximal fourfold reiteration of CACGTG. Transfection of a Max expression plasmid resulted in a two- to threefold decrease, whereas c-Myc caused a two- to threefold increase in luciferase activity compared with transfection with control vector (Fig. 4A). These results are consistent with previous studies indicating that Myc functions as an activator on E-box containing promoters and that overexpression of Max abrogates Myc activation (Amati et al. 1992; Kretzner et al. 1992; Amin et al. 1993; $\mathrm{Gu}$ et al. 1993). Transfection of Mnt expression plasmid caused a nearly sixfold decrease in the background level of luciferase activity as well as a significant reduction in Myc transactivation (Fig. 4A). Mnt failed to repress reporter constructs lacking the CACGTG target site (data not shown), indicating that DNA binding is required for Mnt repression. Cotransfection of equal amounts of Myc and Mnt plasmids, either with or without Max, resulted in repression of transcription. Immunoprecipitation analysis of Myc and Mnt in cotransfected cells indicated that both proteins were expressed at comparable levels (data not shown), suggesting that Mnt repression is dominant over Myc activation on the pGLM4 reporter. Furthermore, both Myc activation and Mnt repression were potentiated by cotransfection with Max. To confirm that transcriptional repression by Mnt is dependent on Max, a dominant negative form of Max lacking its basic region $\triangle B R M a x$ (Kretzner et al. 1992) was used in the transcription assays. Previous studies have shown that repression by Mad1 and activation by $\mathrm{c}-\mathrm{Myc}$ are both reversed by $\triangle B R M a x$ (Ayer et al. 1993). As demonstrated in Figure $4 B$, transfection of $\triangle B R M a x$ relieved repression by Mnt, indicating a dependence on interaction with Max.

\section{Mnt interacts with the mSin3 corepressor}

The results of the transcription assays described above suggest that Mnt:Max complexes have repression activity. This raised the possibility that Mnt, like Mad family members, functions through interactions with corepressor proteins (Ayer et al. 1995, 1996; Schreiber-Agus et al. 1995). Although an initial computer analysis of Mnt failed to reveal any significant homologies with Mad proteins outside of the bHLHZip region, a putative $\alpha$-helical or coiled-coil region was detected at the $\mathrm{N}$-terminus of Mnt using the Coils program (ISREC, data not shown; see Fig. 2B). Further examination of the amino-terminal helical region revealed a small stretch of amino acids exhibiting a striking similarity to the SID found in all Mad family proteins (Fig. 5A) (Ayer et al. 1995; Hurlin et al. 1995b; Schrieber-Agus et al. 1995). The region of homology is limited to a 13 -amino-acid sequence that for Mnt begins immediately following the initiating methionine. Whereas Mad family proteins exhibit extensive homology to each other (Hurlin et al. 1995b), similarity between Mnt and Mad proteins is confined only to their amino termini (SID) and a portion of the bHLHZip region (Fig. 5B).

In vitro interaction assays were performed to determine whether the SID-like domain of Mnt formed a complex with $\mathrm{mSin} 3$ proteins. $\mathrm{mSin} 3 \mathrm{~A}$ was in vitro transcribed, translated, and mixed with either full-length Mnt fused to GST or a GST fusion of a mutant Mnt protein lacking the SID (deletion of amino acids 2-16) (GST-Mnt $\Delta$ SID). As shown in Figure 5C, mSin3A bound 
Hurlin et al.

Figure 3. Mnt:Max binds the preferred $A$ Myc:Max binding site CACGTG, and Mnt and Myc have similar affinities for Max and DNA binding. $(A)$ The indicated proteins were incubated with the ${ }^{32} \mathrm{P}$-labeled probe $\mathrm{CMl}$ containing a single CACGTG site (Blackwood and Eisenman 1991) and analyzed on a native polyacrylamide gel. The locations of the Max homodimer shift and Mnt:Max heterodimer shift are indicated by arrows. Preimmune and immune Max antiserum and preimmune and immune Mnt antiserum were used in the supershift experiments. GST was used as a negative control. (B) Left panel: Increasing amounts (threefold increments) of GST-Mnt in the presence of constant amounts of $\operatorname{Max} 12$ $\mathrm{ng})$ and GST-C176Myc $(10 \mathrm{ng})$ were incubated with the CMl probe. Right panel: Increasing amounts of GST-C176Myc (threefold increments) in the presence of constant amounts of GST-Max (2 ng) and Mnt (20 ng) were incubated with the CM1 probe. In the titrations, the starting amount of GST-Mnt was $2 \mathrm{ng}$ and the starting amount of GST-C176Myc was $1 \mathrm{ng}$, which represent approximately equimolar amounts.

to the full-length GST-Mnt protein, but not to GSTMnt SID or GST-Max. To determine whether Mnt bound to paired amphipathic helix 2 (PAH2) of mSin3A as demonstrated for Madl (Ayer et al. 1995; SchreiberAgus et al. 1995), a deletion mutant of mSin3A lacking PAH2 (mSin3aAPAH2; Ayer et al. 1995) was tested in the interaction assay. Whereas specific binding was again observed between Mnt and full-length mSin3 protein, no interaction was seen with mSin3aAPAH2 (Fig. 5D). These results show that Mnt and Mad family proteins share the ability to interact with $\mathrm{mSin} 3$ corepressor proteins and that the association is mediated through a small, putative amphipathic helical region in the amino terminus of Mnt and the PAH2 region of $\mathrm{mSin} 3$.

The relationship between interaction of Mnt with $\mathrm{mSin} 3$ and transcription repression was tested in transcription assays using the pGL2M4 reporter described above and vectors expressing wild-type $\mathrm{Mnt}$ or Mnt $\Delta$ SID. Whereas wild-type Mnt repressed transcription, Mnt $\Delta$ SID failed to repress and, surprisingly, activated transcription to $\sim 60 \%$ of that detected for c-Myc (Fig. 4C). In addition, cotransfection of Mnt $\Delta$ SID with Myc failed to repress Myc activation. These results demonstrate that transcription repression by Mnt is dependent on an intact SID region and that binding to $\mathrm{mSin} 3$ may mask an activation region in Mnt. We also tested the transcriptional activity of Mnt in primary rat embryo fibroblasts and NIH3T3 fibroblasts, two cell types used to examine the affect of $\mathrm{Mnt}$ on cell transformation (see below). In these cell types, Mnt repressed transcription as in 293 cells, and deletion of the SID caused conversion to an activator (data not shown).

\section{Mnt requires the $m$ Sin 3 interaction domain to suppress Myc-dependent transformation}

The ability of Mnt to repress transcription activation by Myc suggested that Mnt might antagonize biological ac- tivities of Myc. We used the Myc+Ras cotransformation assay (Land et al. 1983) to test the ability of Mnt to affect transformation of primary rat embryo fibroblasts (REFs). REFs were transfected with the plasmids indicated in Table 1 and foci of transformed colonies scored 2 weeks later. Inclusion of Mnt expression plasmid with Myc and Ras reduced the number of foci generated with Myc and Ras by an average of $86 \%$ based on five independent experiments /Table 1, experiments 2-6 in which equal amounts of transfected plasmids were used and see Fig. 6). Mad4 inhibited focus formation by Myc and Ras to a similar degree as Mnt (data not shown and Hurlin et al. 1995b). However, transfection of the Mnt $\Delta$ SID plasmid failed to suppress Myc/Ras transformation. Because this Mnt mutant could activate transcription at Myc:Max Ebox sites (Fig. 4C), we tested whether it would substitute for Myc in the cotransformation assay. Figure 6 and Table 1 show that whereas neither Ras nor Mnt $\Delta$ SID alone caused focus formation, cotransfection of the two plasmids generated significant numbers of foci, albeit at a lower efficiency than $\mathrm{Myc}$ and Ras. Immunoprecipitation analysis using anti-Mnt serum revealed a protein with the mobility expected for Mnt $\Delta$ SID in Mnt $\Delta$ SID/ Ras foci (data not shown). Thus, deletion of the SID converts Mnt from a suppressor of transformation to a cooperating oncogene. Importantly, the ability of wildtype Mnt to block transformation appeared to be specifically related to its effects on Myc, as it failed to inhibit transformation of NIH-3T3 cells by activated Ras alone (Table 1).

\section{Mnt:Max and Myc:Max complexes coexist in proliferating cells}

We examined mnt mRNA expression by Northern blot analysis using poly(A) selected RNAs from a variety of adult mouse tissues, as well as from human keratino- 


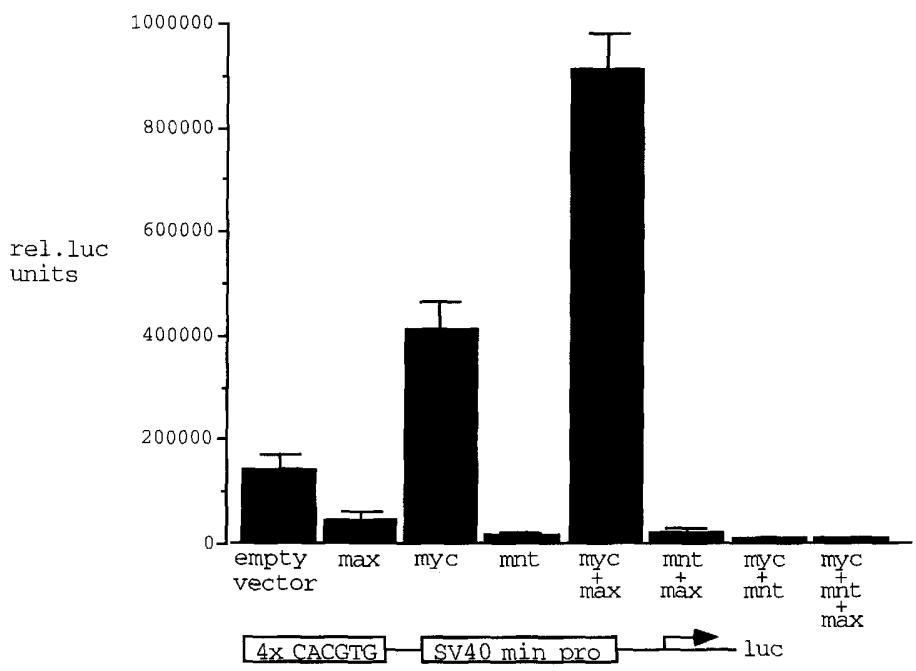

B

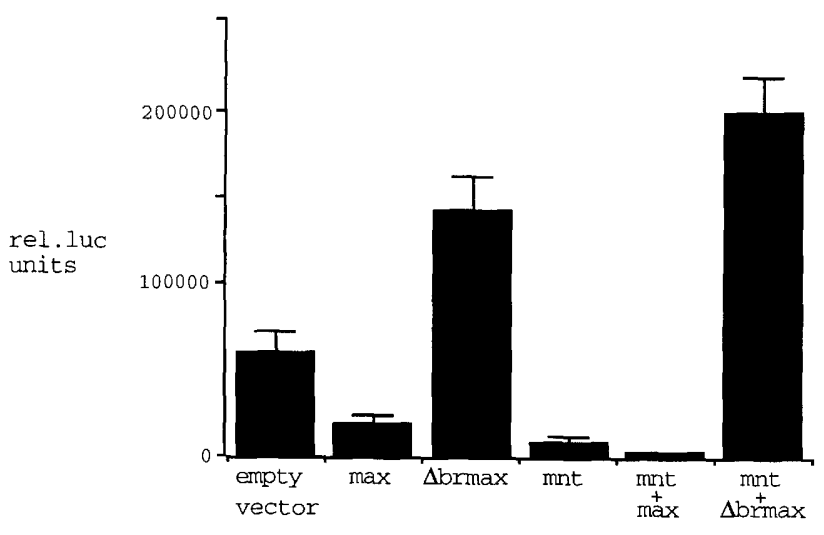

C

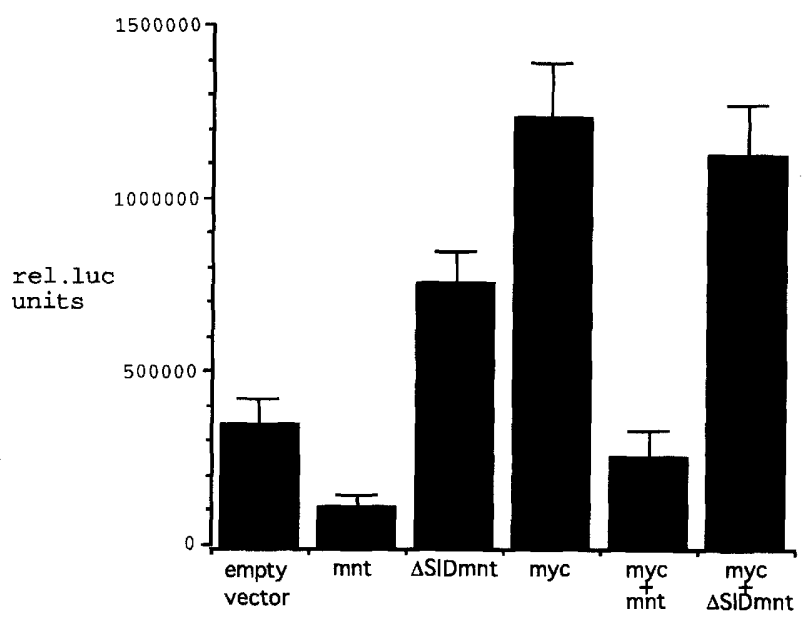

Figure 4. Mnt is a transcriptional repressor. 293 cells were transfected in triplicate with $3 \mu \mathrm{g}$ of the indicated plasmids. Luciferase activity produced by the cotransfected pGL2M4 reporter plasmid (containing four CACGTG binding sites) was determined from cell lysates $48 \mathrm{hr}$ later (see Materials and Methods). Luciferase activity was normalized to $\beta$-galactosidase activity derived from the cotransfected plasmid pCMVbGAL as described previously (Kretzner et al. 1992). Results are presented as mean \pm S.E.M..

cytes and rat PC12 cells. An $\sim 5$-kb message was detected in these tissues and cell lines (data not shown). To determine whether mnt expression was specific to subpopulations of proliferating or differentiating cell types, in situ hybridization was performed on embryos at different stages of development [embryonic day (e) 9.5, 10.5, and 12.5]. mnt expression was detected uniformly throughout embryos at e9.5 and 10.5 (Fig. 7), but at later stages appeared to be highest in neural structures /neural tube and spinal and cranial ganglia, data not shown). Comparison of mnt with c- and N-myc expression at e10.5 (Fig. 7), as well as at other stages, clearly demonstrated overlapping patterns of expression. However, whereas c- and N-myc are expressed primarily in proliferating cell compartments, mnt is expressed in both pro- liferating and differentiating cells /e.g., N-myc is expressed in the proliferating ventricular zone of the neural tube and mnt is expressed in both the ventricular and in the intermediate zone populated by differentiating cells; Fig.7, see arrows).

The in situ hybridization results suggested that Myc and Mnt proteins might coexist in separate complexes with Max in proliferating cells. In order to identify Mnt proteins in cells we prepared a rabbit polyclonal antiserum against the GST-Mnt (bHLHZip) fusion protein. This Mnt antiserum specifically recognized a $72-\mathrm{kD}$ protein produced by in vitro transcription and translation of the mnt cDNA. In 293 cells transfected with mnt cDNA expression vector, a $72-\mathrm{kD}$ protein was produced that comigrated with the in vitro translated protein (not 


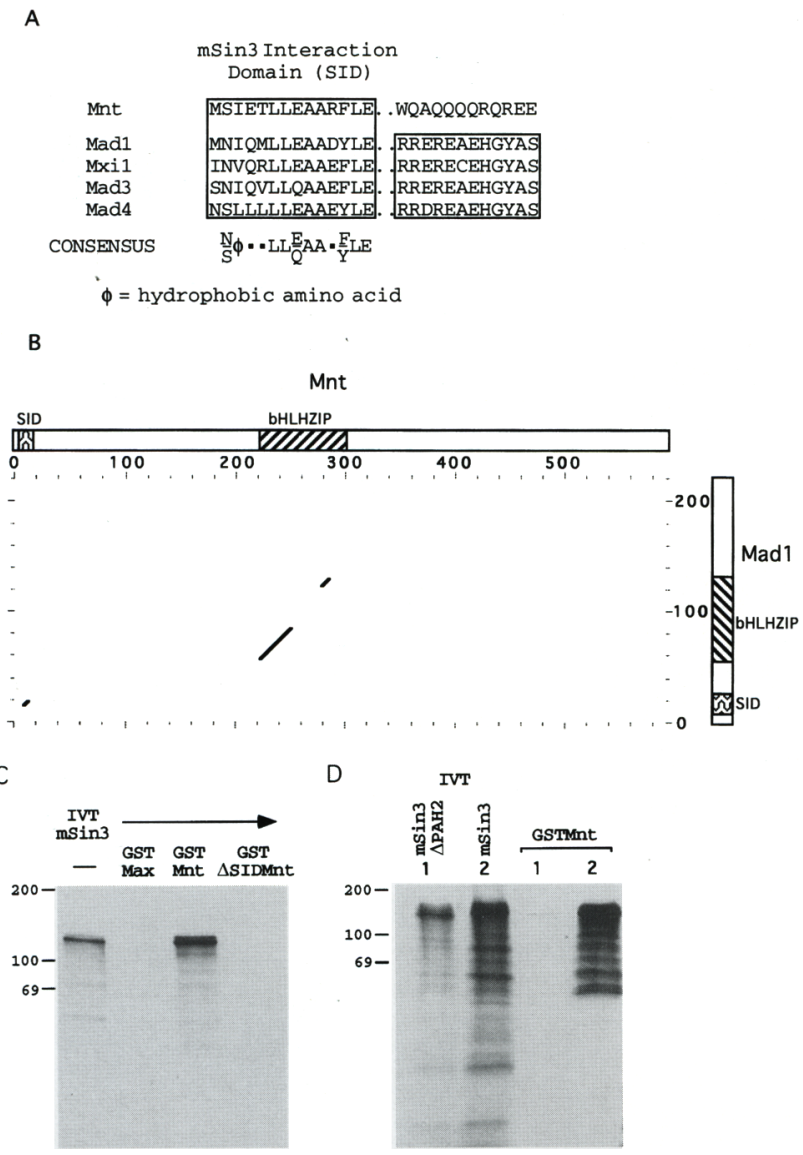

Figure 5. The amino-terminal region of Mnt interacts with $\mathrm{mSin} 3$ corepressor proteins. (A) Alignment of the first 26 amino acids of Mnt with the region of Mad proteins containing the SID. Consensus amino acids are indicated. $(B)$ Dot-plot analysis (GCG, Compare program; stringency 19) of Mnt and Mad1 shows that similarity is restricted to the SID and to the bHLHZip region. $(C)$ Ten microliters of in vitro translated $\mathrm{mSin} 3 \mathrm{~A}$ was incubated with GST-Max, GST-Mnt, or GST- $\Delta$ SIDMnt (deletion of amino acids 2-16 of Mnt) in the presence of glutathione-Sepharose beads. Proteins remaining bound following washing were released and analyzed on $12.5 \%$ polyacrylamide gels. One microliter of in vitro translated $\mathrm{mSin} 3 \mathrm{~A}$ is shown on the left side of the figure. $(D)$ In vitro translated $\mathrm{mSin} 3$ a deleted for PAH2 (mSin $3 a \Delta P A H 2)$ (1) and $\mathrm{mSin} 3 \mathrm{a}$ were incubated with GST-Mnt and analyzed as in $C$.

shown). In addition, a 74-kD protein was observed (see Fig. 8A). The 72 - to $74-\mathrm{kD}$ doublet produced in 293 cells by the mnt expression vector was present in low stringency anti-Max immunoprecipitates and was specifically immunoprecipitated from disrupted Max complexes by the Mnt antiserum (Fig. 8A). Pulse-chase experiments revealed that the $74-\mathrm{kD}$ protein is derived from in vivo modification of the $72-\mathrm{kD}$ protein and that these Mnt proteins are rapidly degraded with a half-life of 30-60 min (data not shown). Furthermore, Mnt antiserum specifically precipitated a $72-$ to $74-\mathrm{kD}$ doublet from a number of murine, rat, and human cell types. Subcellular fractionation of lysates made from rat PC12
Table 1. Effect of Mnt on REF and NIH-3T3 fibroblast transformation

\begin{tabular}{lcccccc}
\hline $\begin{array}{l}\text { A. Rat embryo fibroblasts } \\
\text { Transfected }\end{array}$ & 1 & 2 & 3 & 4 & 5 & 6 \\
\cline { 2 - 7 } plasmids $^{\text {a }}$ & 50 & 29 & 66 & 156 & 183 & 70 \\
\hline Myc+Ras $^{\text {b }}$ & $11 / 6^{\mathrm{c}}$ & 2 & 10 & 18 & 26 & 14 \\
Myc+Ras+Mnt & - & - & 71 & 167 & 137 & - \\
Myc+Ras+Mnt $\Delta$ SID & - & - & - & 25 & 21 & - \\
Myc+Ras+Mad4 & - & - & - & - & 134 & 43 \\
Mnt $\Delta$ SID+Ras & - & - & - & - & 2 & 3 \\
Ras & - & - & - & - & - & 0 \\
Mnt $\Delta$ SID & 0 & 0 & 0 & - & - & - \\
Empty vector & & &
\end{tabular}

B. NIH-3T3

\begin{tabular}{lcc} 
Transfected & \multicolumn{2}{c}{ Experiment no. } \\
\cline { 2 - 3 } Plasmids $^{\mathrm{a}}$ & 1 & 2 \\
\hline Ras & 52 & 46 \\
Mnt+Ras & 56 & 53
\end{tabular}

a Three micrograms of the indicated plasmids plus empty plasmid when necessary in order to equalize total plasmid DNA transfected.

${ }^{\mathrm{b}}$ EJ c-Ha-Ras ${ }^{(\text {Val 12) }}$.

c Number of foci generated when either 1 or $5 \mu \mathrm{g}$ of $\mathrm{Mnt}$ plasmid was added.

cells and human keratinocytes followed by Western blotting using the Mnt antiserum revealed that the 72 - to 74-kD Mnt doublet is specifically present in the nucleus (data not shown). Consistent with the in situ hybridization results (Fig. 7), the Mnt protein was detected in cells during log phase growth, as well as in growth-arrested differentiated cells (data not shown).
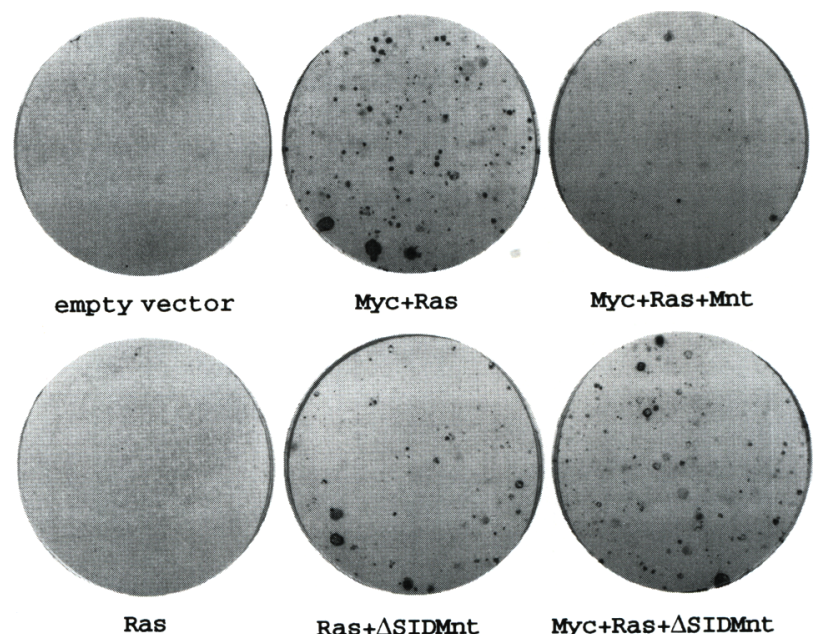

Myc+Ras+Mnt

Ras $+\Delta$ SIDMnt

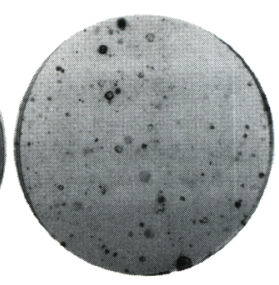

MYC+Ras+ $\Delta$ SIDMnt

Figure 6. Mnt suppresses Myc/Ras transformation of rat embryo fibroblasts. Shown are representative plates containing REF cells stained with methylene blue 2 weeks following transfection with the indicated plasmids. Equal amounts $(3 \mu \mathrm{g})$ of plasmids were used. 

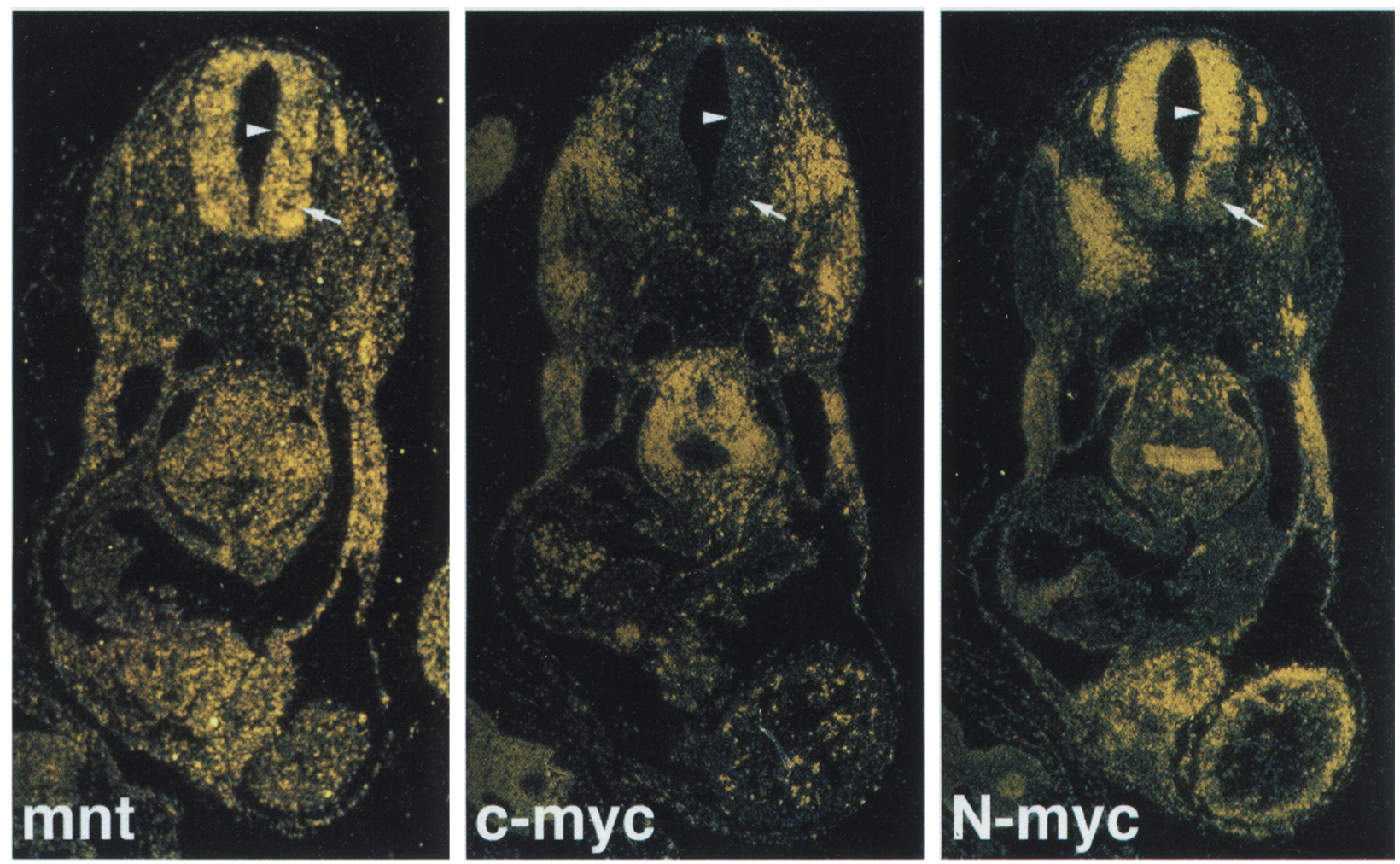

Figure 7. Comparison of mnt, c-myc, and N-myc expression at e10.5 of mouse development by in situ hybridization. Transverse sections were hybridized with $m n t, c-m y c$, and $\mathrm{N}-m y c$ antisense probes as described previously (Hurlin et al. 1995b). The arrow head points to the proliferative ventricular zone of the neural tube and the arrow to the intermdiate zone containing differentiated neurons and glia.

The above experiments demonstrated that overexpressed Mnt can be detected in a complex with Max. In order to determine whether endogenous Mnt and Max proteins interact and whether both Mnt:Max and Myc: Max complexes coexist during cell proliferation, we used the MCF-7 human breast carcinoma and the HLF human neuroblastoma cell lines. Max was immunoprecipitated from $\left[{ }^{35} \mathrm{~S}\right]$ methionine-labeled logarithmically growing cells under low-stringency (LS) conditions. Proteins associated with Max were then eluted under high-stringency (HS) conditions and reimmunoprecipitated using the Mnt and Myc antisera as described previously (Blackwood et al. 1992b; Ayer and Eisenman 1993; and see Materials and Methods section). In both cell lines, Mnt and Myc (c-Myc in MCF-7 cells and N-Myc in HLF cells) could be detected following reimmunoprecipitation of anti-Max complexes (Fig. 8B and data not shown). The Max doublet at 21-22 kD was also observed following longer exposures (not shown). These results indicate that Mnt:Max and Myc:Max heterocomplexes are both present in proliferating cell populations.

\section{Early embryonic lethality and proliferation defects in Mnt transgenic mice}

The experiments described above demonstrate that Mnt can oppose the activity of Myc in transcription and transformation assays and that it is coexpressed with Myc and Max in a wide variety of proliferating cell types. Because Myc family proteins are known to be crucial for early embryogenesis, we examined whether the regulation of Mnt expression was also important during development and whether Mnt overexpression in vivo might antagonize Myc functions. To investigate Mnt function in vivo we produced transgenic mice expressing mnt under the control of the $\beta$-actin promotor. Litters generated from microinjected pronuclei were obtained and genotyped. No pBAPmnt transgenic pups could be identified by Southern blotting (Table 2 and data not shown), suggesting that transgenic embryos died in utero. To determine whether an early embryonic phenotype could be identified, embryos generated from mnt microinjected blastocysts were isolated at e8.5, 9.5, 10.5, and 12.5. At e12.5 there were very few live embryos and many empty decidua, suggesting that the majority of embryos had been resorbed (Table 2). The pBAPmnt transgene was not detected in any of the live embryos recovered at e12.5 (Table 2). At e10.5 the number of live embryos per litter was also low, and of the eight embryos recovered, two were very small (Fig. 9A). Similar to e10.5, both normal and small embryos were recovered at e9.5 (Table 2; Fig. 9). At e8.5 the litter sizes were larger and the percentage of small embryos was greater than at e9.5 and e10.5 (Table 2). PCR genotyping revealed that all but one of the 


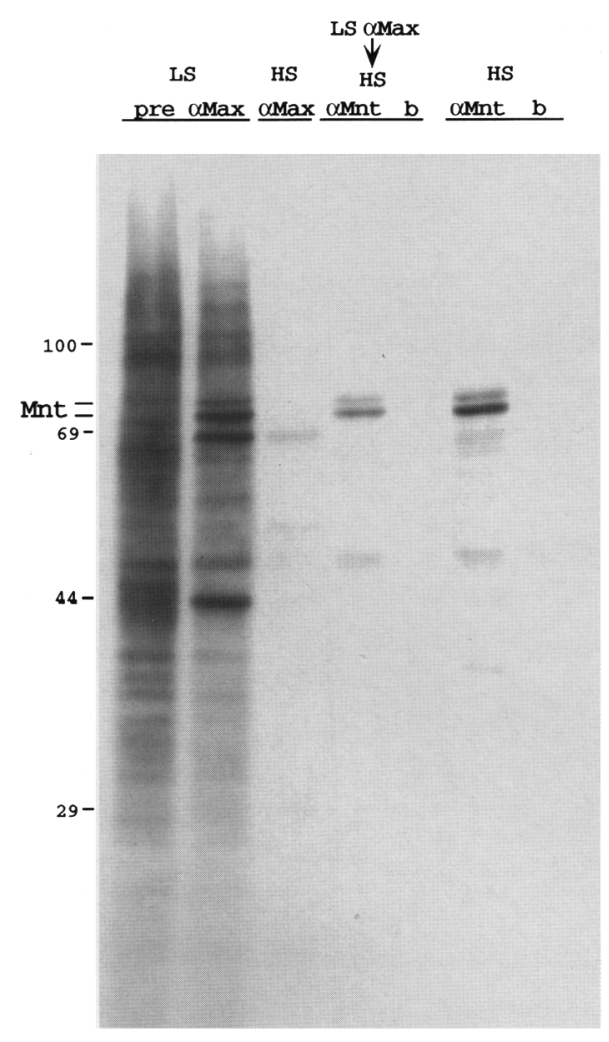

B

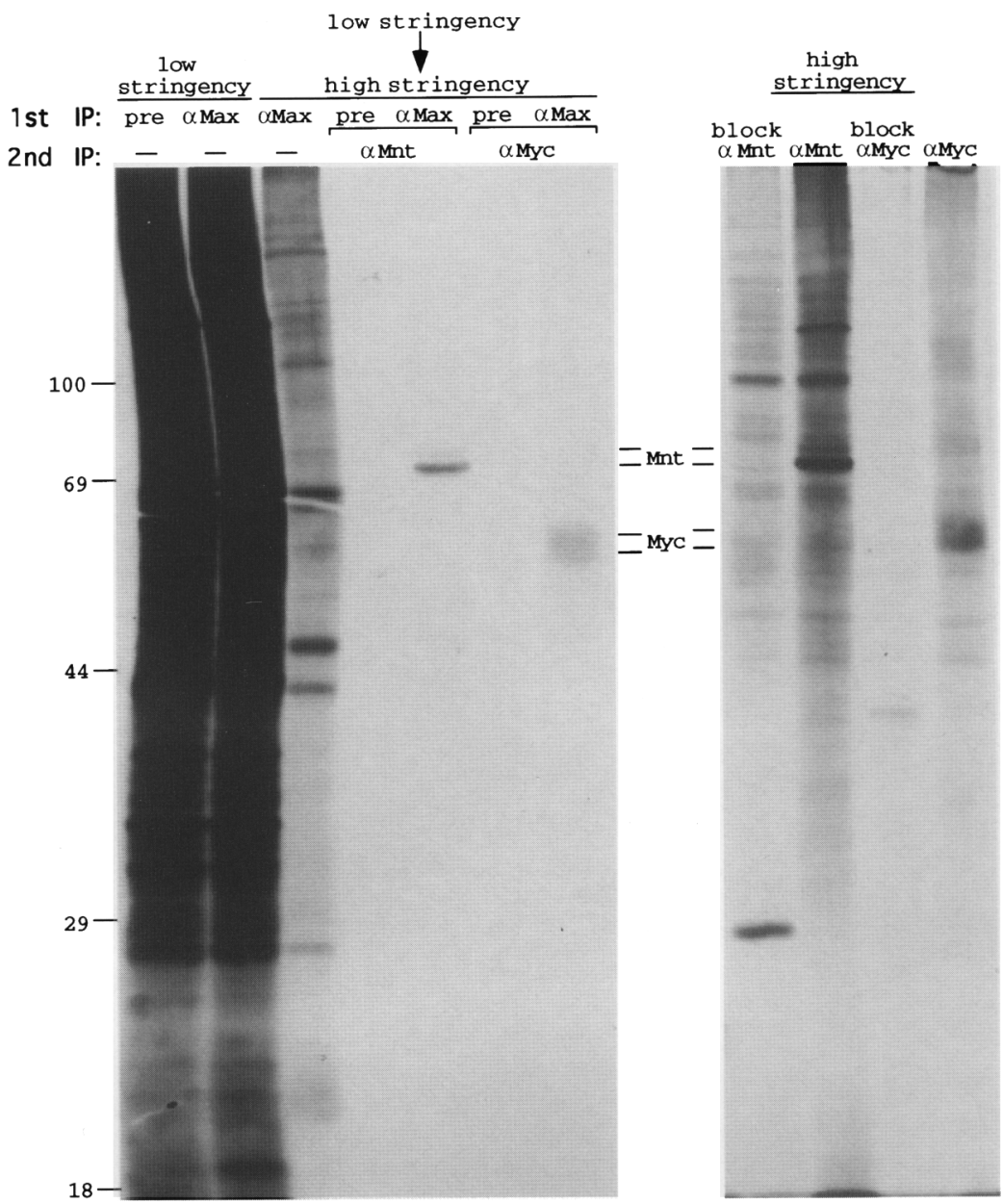

Figure 8. Mnt and Max associate in vivo. (A) 293 cells transfected with mnt expression plasmid. Cells were labeled with [ $\left.{ }^{35} \mathrm{~S}\right]$ methionine $48 \mathrm{hr}$ after transfection and LS cell lysates prepared and immunoprecipitated with either Max immune serum ( $\alpha \mathrm{Max}$ ) or preimmune (pre) from the same rabbit. LS Max immunoprecipitations were resuspended in HS buffer to elute complexed proteins and reimmunoprecipitated with Mnt antiserum or Mnt antiserum blocked (b) with immunogen. (B) Endogenous Mnt:Max and Myc:Max complexes coexist in proliferating cells. LS lysates from ${ }^{35} \mathrm{~S}$-labeled MCF-7 breast carcinoma cells in log-phase growth were prepared and immunoprecipitated with either Max preimmune or immune serum as above. Immunoprecipitated proteins (from both preimmune and immune precipitations) were eluted under HS conditions and reimmunoprecipitated with either Mnt or Myc antiserum. Lysates prepared in HS buffer (right side) were analyzed using Mnt and Myc antiserum.

small embryos recovered at $\mathrm{e} 8.5,9.5$, and 10.5 contained the pBAPmnt transgene, and that only one of the embryos that appeared morphologically normal tested positive for the mnt transgene (Table 2, data not shown).

The most striking difference between mnt transgenic and nontransgenic embryos was embryonic size. As shown in Figure 9, the disparity in size between nontransgenic and mnt transgenic embryos recovered increased from e8.5 to e10.5. mnt transgenic embryos at e8.5 were near the size of their nontransgenic littermates (Fig. 9). Furthermore, because the majority of transgenic embryos recovered at e8.5, 9.5, and 10.5 appear to be approximately equivalent to e8.5-size embryos, Mnt overexpression may cause a delay or termination of development near that stage. In addition to embryonic size, however, there was a range of phenotypes presented among the pBAPmnt transgenic embryos, including embryos that appeared morphologically normal (see middle embryo at e10.5) to those exhibiting dramatic defects in head and body plan morphogenesis. For example, several pBAPmnt embryos exhibited a wavy neural tube and/or lacked proper head region development (see e10.5 embryo at right and data not shown). The specific cell or tissue types affected in these embryos is currently under investigation, but preliminary findings indicate defective neural tissue proliferation and differentiation, as well as possible defects in surrounding supportive mesodermal tissues. Other embryos showed a dramatic lack of cellularity (see e9.5 embryo at right and data not shown). It is likely that the range of phenotypes observed 
Table 2. Analysis of pBAPmnt embryos

\begin{tabular}{lccccc}
\hline & & & \multicolumn{3}{c}{ Phenotype and genotype $^{\mathrm{a}}$} \\
\cline { 5 - 6 } Age & $\begin{array}{c}\text { Number } \\
\text { of litters }\end{array}$ & $\begin{array}{c}\text { Number } \\
\text { of pups }\end{array}$ & $\begin{array}{c}\text { no. } \\
\text { normal }\end{array}$ & $\begin{array}{c}\text { no. } \\
\text { small }\end{array}$ & $\begin{array}{c}\% \\
\text { small }\end{array}$ \\
\hline $8.5^{\mathrm{b}}$ & 2 & 13 & $7(1)$ & $6(5)$ & 46 \\
$9.5^{\mathrm{b}}$ & 6 & 13 & $9(0)$ & $4(4)$ & 31 \\
$10.5^{\mathrm{b}}$ & 4 & 8 & $6(0)$ & $2(2)$ & 25 \\
$12.5^{\mathrm{b}}$ & 3 & 5 & $5(0)$ & 0 & 0 \\
1 week $^{\mathrm{c}}$ & 6 & 19 & $19(0)$ & - & 0
\end{tabular}

${ }^{a}$ Number of transgene positive embryos among the indicated phenotypes are shown in parentheses. Embryo yolk sac-derived DNA was genotyped by PCR and newborns were genotyped by PCR and Southern blotting on tail DNA.

${ }^{\mathrm{b}}$ Days of gestation.

${ }^{c}$ One week after birth.

is caused by variability in transgene expression levels among the different embryos, as well as by transgene mosaicism (Wilkie et al. 1986).

\section{Discussion}

The model that the biological functions of Myc are mediated through binding and transcriptional activation of specific target gene promoters by Myc:Max heterodimers has received a great deal of experimental support (for review, see Blackwood et al. 1992a; Amati and Land 1994; Henriksson and Lüscher 1996). Other mechanisms, such as transcriptional repression by Myc, also may be relevant (Roy et al. 1993; Li et al. 1994), but recent evidence suggesting that at least some of the biological effects of Myc can be mimicked by overexpression of putative target genes such as ODC and cdc25a (Bello-Fernandez et al. 1993; Packham and Cleveland 1994; Galaktionov et al. 1996) underscores the importance of Myc's activator function. Given the relevance of the interaction of Myc with Max, and the subsequent binding of Myc:Max dimers to target genes, it would be expected that other Max binding proteins could potentially exert powerful effects on Myc's activities. In this paper we describe the novel Max-interacting protein, Mnt, that is coexpressed with Myc proteins and appears to bind a common set of target genes in vivo. We find that mnt RNA is present in a wide range of embryonic cell types together with $\mathrm{N}$ - and c-myc RNAs (Fig. 7; data not shown). In addition, we find that in proliferating MCF-7 breast carcinoma cells (Fig. 8) as well as in a neuroblastoma cell line (not shown), that Mnt protein is coexpressed with c-Myc and N-Myc proteins, respectively. More important, we find that Mnt:Max and Myc:Max complexes coexist in proliferating cells (Fig. 8). It is not known whether Max is limiting in the cells examined here, but if so it is possible that Mnt and Myc compete for interaction with Max and that such competition regulates Myc functions. However, previous work has indicated that Max is significantly in excess of Myc, at least in NIH-3T3 cells (E.M. Blackwood and R.N. Eisen-

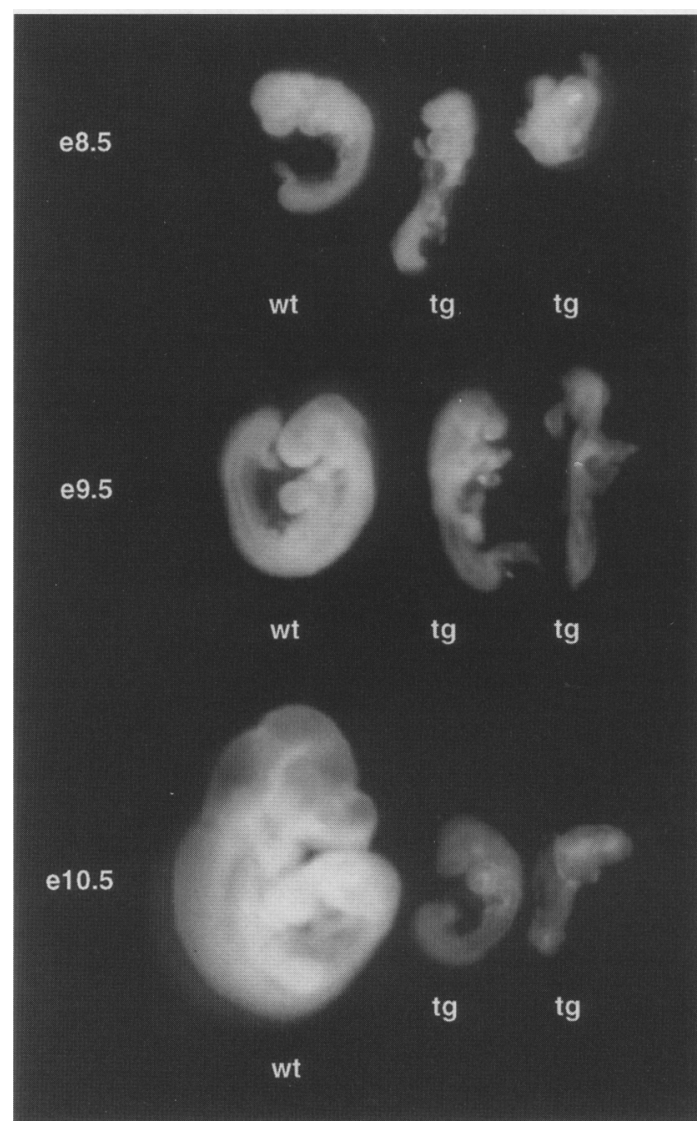

Figure 9. Comparison of pBAPmnt transgenic embryos with wild-type embryos. Embryos were recovered at 8.5, 9.5, and 10.5 days of gestation. Wild-type embryos (left) and two pBAP-mnt transgene-positive embryos from each indicated day of gestation are shown. Presence (tg) or absence [wild type (wt)] of the transgene was determined by PCR genotyping (see Materials and Methods).

man, unpubl.) and it therefore seems more likely that Mnt:Max and Myc:Max complexes would compete for binding to common target sites. Our data demonstrate that Mnt binds Myc:Max target sites in vitro (Fig. 3) and is a transcriptional repressor in many different cell types (Fig. 4; data not shown; see below) and therefore implies that binding by Mnt:Max would antagonize Myc:Max transcriptional activity and Myc functions. Indeed, the ability of wild-type Mnt to suppress Myc-dependent transformation, and of a mutant form of Mnt lacking its transcription repression domain (SID) to partially substitute for Myc in transformation assays, is evidence that Mnt:Max and Myc:Max regulate common target genes in vivo. (Fig. 6; Table 1).

\section{Mnt exhibits both Mad and Myc functions}

In several of its properties Mnt appears similar to the Mad family proteins. First, both Mnt and the Mad proteins interact with the PAH2 region of the $\mathrm{mSin} 3$ corepressor proteins through a related SID. Second, the SID is 
also required for both Mad and Mnt transcriptional repression (Fig. 5C; Ayer et al. 1995; Hurlin et al. 1995b; Schrieber-Agus et al. 1995) and suppression of transformation (Fig. 6; Koskinen et al. 1995). However, outside of the 13-amino-acid SID homology region and the bHLHZip domain, Mnt and Mad proteins show little or no homology. Interestingly, Mnt contains regions with similarity to proline-rich activation domains, as does Myc. Deletion of the Mnt SID domain not only abolishes transcription repression, but also converts $\mathrm{Mnt}$ to a transcriptional activator (Fig. 4C) and an oncogene capable of cotransforming cells with an activated Ras (Fig. 6). Therefore it is possible that the SID domain of Mnt masks a Myc-like transcription activation function. The ability of the SID to inhibit the activity of a linked transactivator is consistent with recent studies demonstrating that SID repression is dominant when fused to either VP16 or Myc (Ayer et al. 1996; Harper et al. 1996). At this point, however, the putative trans-activation domain of Mnt has not been mapped and it is unclear what role might be served by such a domain. One possibility is that $\mathrm{mSin} 3$ binding to the SID domain is regulated, for example, by alternative splicing, as it is for Mxil (Schreiber-Agus et al. 1995), providing a mechanism for switching from transcription represson to activation, as has been observed for several other transcription factors (for review, see Johnson 1995). While this paper was in preparation we learned that Meroni et al. (G. Meroni, A. Ballabio, D.H. Ledbetter, and R. Carrozzo, in prep.), have also cloned mnt (rox in their designation) and detected transcriptional activation by Mnt/Rox in the HeLa cervical carcinoma cell line. We have confirmed their results; however, we have found that Mnt repressed transcription in a different cervical carcinoma cell line (C33A), as it did in several other cell types tested, including primary rat embryo cells, in which Mnt blocks cotransformation by Myc and Ras (Fig. 6; Table 1, and data not shown). These findings suggest that Hela cells represent a unique case, perhaps related to the presence of human papilloma virus. It is possible therefore, that transcription activation by Mnt may be biologically relevant in some contexts, with implications for cell transformation. Nonetheless, our data strongly indicate that the predominant transcriptional activity of Mnt is repression.

In its apparent ability to homodimerize, at least in vitro (Fig. 1B), Mnt is similar to Max and unlike any of the other Max-interacting proteins described thus far. However, we have not been able to demonstrate DNAbinding activity of Mnt homodimers either in vitro or in vivo (Fig. 3A; data not shown). It is possible that DNA binding by Mnt homodimers requires modifications of the Mnt protein that are absent in the bacterially purified preparations used in these assays. Alternatively, Mnt homodimers may interact with as yet undetermined DNA sequences.

\section{Influence of Mnt on transcription activation by Myc}

The transcription activation domains within the amino- terminal region of Myc proteins were originally identified by testing portions of c-Myc fused to the DNA-binding domain of GAL4 with a reporter construct containing GAL4 binding sites (Kato et al. 1990). These experiments revealed a tripartite trans-activation domain that activates transcription 30- to 100-fold (Kato et al. 1990). Studies in yeast show even stronger activation by Myc:Max, in the range of a 1000-fold (Amati et al. 1992; Crouch et al. 1993). However, transient transfection of Myc in a variety of mammalian cell types results in relatively modest 2 - to 10 -fold activation of reporter genes containing the preferred Myc:Max binding site CACGTG proximal to a minimal promoter or to more complex target gene promoters (Fig. 4A,C; Bello-Fernandez et al. 1993; Wagner et al. 1993; Desbarats et al. 1996; Galaktionov et al. 1996; Grandori et al. 1996). These results suggest that Myc proteins may have a stronger intrinsic transcriptional activity than is manifested in mammalian cells, and raise the possibility that other factors may function to limit Myc trans-activation. Because Mnt and $\mathrm{mSin} 3$ are expressed in many proliferating mammalian cell types used to investigate transcription regulation by Myc, including human 293 cells used in this study (data not shown), it is possible that Mnt:Max: Sin3 repressor complexes are responsible, possibly in concert with other factors (Gaubatz et al. 1995), for restricting maximal activation at common target gene promoters by Myc. Consistent with this notion, we show that reporter transcription is repressed in cells transfected with equal amounts of myc and mnt plasmids (Fig. 4A), even though Myc and Mnt proteins appear to be expressed at similar levels (not shown) and have similar DNA-binding affinities (Fig. 3B). Although more detailed studies on specific target promoters will be required, our data are consistent with the notion that a program of repression must be overcome for Myc to activate target genes in vivo.

\section{Mnt suppression of Myc activities in vivo?}

If the ratio of Mnt to Myc protein is an important determinant of Myc function, then we might expect that because myc family gene expression is important in murine embryogenesis (Charron et al. 1992; Stanton et al. 1992; Davis et al. 1993; Moens et al. 1993; Sawai et al. 1993), overexpression of Mnt would have a deleterious effect on mouse development. Embryos containing an $m n t$ transgene under the control of the $\beta$-actin promoter appeared to die primarily between day 8.5 and day 10.5 of gestation in association with a range of phenotypes. Endogenous mnt is expressed throughout the embryo between e9-12 (Fig. 7 and data not shown), suggesting, but not proving, that it is elevated Mnt levels, and not ectopic expression in tissues that do not normally express $\mathrm{Mnt}$, that is responsible for the range of phenotypes observed. mnt transgenic embryos were consistently smaller than wild-type littermates, raising the possibility that a general lack of proliferation may be at least partially responsible for the lethality observed. Indeed, several of the mnt transgenic embryos showed a dra- 
matic decrease in cellularity (see Fig. 9, e9.5 embryo at far right and data not shown) consistent with this possibility. It is interesting that homozygous deletion of c- or $\mathrm{N}$-myc also resulted in decreased cellularity and embryonic lethality in approximately the same time frame as mnt transgenic animals (Charron et al. 1992; Stanton et al. 1992; Davis et al. 1993; Moens et al. 1993; Sawai et al. 1993). Many mnt transgene-positive embryos appear more severely affected than the c- and $\mathrm{N}-m y c$ knockout animals, possibly a result of suppression of both c- and $\mathrm{N}-\mathrm{Myc}$ functions. However, the range and complexity of phenotypes observed in $m n t$ transgenic animals makes it very difficult to make any direct comparisons between the mnt overexpression and myc knockout phenotypes. It will now be important to target Mnt expression in a conditional or tissue-specific manner to better define its affects on cell proliferation and differentiation and on Myc functions in vivo.

The ability of Mnt overexpression to suppress Mycdependent transformation and potentially affect developmental functions of Myc suggests that the relative levels of Myc and Mnt may be important in regulating cell proliferation. Studies employing hypomorphic $\mathrm{N}-m y c$ alleles in mice have demonstrated that even small perturbations in the normal levels of myc expression can have significant tissue-specific effects (Moens et al. 1993). Mnt:Max may impose a program of repression at Myc target sites that is overridden when Myc levels are altered such as during the $G_{0}-G_{1}$ transition (Kelly et al. 1983; Campisi et al. 1984; Armelin et al. 1984), gastrulation and organogenesis (Fig. 8; Downs et al. 1989; Schmid et al. 1989), and tumorigenesis (Hann and Eisenman 1984). The antagonistic relationship between Myc and Mnt also raises the possibility that decrease or loss of Mnt expression, perhaps caused by deletion or disruption of the Mnt genomic locus, might in effect activate the transforming properties of Myc proteins. The chromosomal mapping of mnt in the mouse to chromosome 11 , syntenic to human chromosome $17 \mathrm{p} 13.3$ (E. Steingrimmson, P.J. Hurlin, R.N. Eisenman, and N. Copeland, in prep., human position confirmed by D.H. Ledbetter, pers. comm.), will allow investigation of this possibility. Loss of heterozygosity in this region is consistently observed in several tumor types in which the putative tumor suppressor gene has not yet been identified (Litofsky et al. 1994; Phillips et al. 1996).

\section{Materials and methods}

\section{Yeast two-hybrid screen and Mnt1 cloning}

The yeast two-hybrid screen in which Mnt1 was identified was described previously (Hurlin et al. 1995b). Briefly, an L40 yeast strain expressing Max 9 as a fusion protein with the DNA-bind. ing domain of LexA was transformed with a library of cDNA fragments from 9.5- and 10.5-day-old embryos fused to the trans-activation domain of VP16/the version of the two-hybrid system used here is described in detail by Hollenberg et al. 1995). Of 67 colonies identified that tested positive for growth on media lacking histidine and expression of $\beta$-galactosidase, two clones (13 and 18) contained independent cDNAs coding for
Mnt. A 4570-bp mnt cDNA was cloned from a murine fetal brain library (Stratagene). The mnt cDNA was sequenced using a series of nested exonuclease deletions in both orientations (Henikoff 1984) and with specific oligonucleotide primers. For sequencing, an Applied Biosystems automated sequencing apparatus was used.

\section{Subcloning and mutagenesis}

The GST fusion proteins used included (1) the partial Mnt open reading frame derived from the two-hybrid library clone 18 (coding for amino acids 139-271) subcloned directly into pGEX3x (Pharmacia) to generate pGEXclone18, (2) the PCR-amplified Mnt bHLHZip region (coding for amino acids 109-214, 5' oligo: nucleotides 318-339, $3^{\prime}$ oligo: 621-642) cloned into pGEX2T (pGEXMnt bHLHZip), (3) the PCR amplified full-length Mnt open reading frame $\left(5^{\prime}\right.$ oligo: nucleotides $\left(-19-12,3^{\prime}\right.$ oligo, nucleotides 1756-1777) cloned into pGEX2T (pGEXMnt), and (4) PCR-amplified $m n t$ deleting nucleotides $4-48$ (coresponding to amino acids 2-16) (5' oligo, nucleotides $-9-3,3$ ' oligo: nucleotides 1787-1809) cloned into pGEX2T (pGEXMnt $\Delta$ NT16). $B a m H I$ and EcoRI sites were engineered into each of the $5^{\prime}$ and 3 ' oligos, respectively, for cloning into pGEX vectors. The nucleotide numbers listed refer to the sequence of the Mnt open reading frame (i.e., A of the ATG start codon is number 1).

The Mnt mammalian expression vectors included $\{1\}$ the entire 4565-bp mnt cDNA cloned into the vector pRC-CMV (Invitrogen) and pSP271 (a gift of M. Emerman, Fred Hutchinson Cancer Research Center, Seattle, WA) to generate pRCmnt and pSpmnt lusing HindIII-NotI and HindIII-BamHI fragments, respectively|. To generate Mnt $\Delta \mathrm{NT} 16$, the same PCR product used to generate pGEXMnt $\Delta$ NT16 (see above) was cloned into pVZ1 (Henikoff and Eghtedarzadeh 1987). The mnt $\Delta$ NT16 sequence in $\mathrm{pVZ1}$ was subcloned into pRcCMV (pRCMnt $\Delta \mathrm{NT} 16)$ and pSp271 (pSPMnt $\Delta$ NT16) using HindIII-EcoRl and HindIII$B a m H I$ fragments, respectively.

\section{Antibodies and immunoprecipitations}

To generate Mnt antiserum (serum \#6823H), the GST-MntbHLHZip fusion protein (see above) was used as immunogen for immunizing a New Zealand white rabbit. The immunogen was used to control for specificity in immunoprecipitations by preincubation with the Mnt antiserum. Max (serum \#8711) and Myc (serum \#1537) antiserum have been described previously (Blackwood et al. 1992b). For detection of Mnt in transfected cells, $5 \times 10^{6}$ cells were metabolically labeled for $45 \mathrm{~min}$ using $250 \mu \mathrm{Ci}\left[{ }^{35} \mathrm{~S}\right]$ methionine (Amersham). Immunoprecipitations of untransfected cells were performed using $1 \times 10^{7}$ to $5 \times 10^{7}$ cells labeled with $400 \mu \mathrm{Ci}\left[{ }^{35} \mathrm{~S}\right]$ methionine. In experiments to detect Max, cells were metabolically labeled for 1-2 $\mathrm{hr}$ to increase the specific activity of Max polypeptides (Blackwood et al. 1992b). LS immunoprecipitations were performed in LS buffer $[20 \mathrm{mM}$ HEPES at $\mathrm{pH} 7.5,100 \mathrm{~mm} \mathrm{KCl}, 10 \mathrm{mM} \mathrm{MgCl} 2,5 \mathrm{~mm}^{2}$ dithiothreinol (DTT), and $0.2 \%$ NP-40] containing $0.5 \%$ aprotinin and 0.2 mM phenylmethysulfonyl fluoride (PMSF). For the detection of Max-associated proteins, LS Max immunoprecipitations were collected on protein A-Sepharose beads and washed 3 times with LS buffer. Complexed proteins were either eluted and analyzed directly or the protein A-Sepharose beads were incubated in $\mathrm{HS}$ buffer $(20 \mathrm{~mm}$ Tris- $\mathrm{HCl}$ at $\mathrm{pH} 7.4,50 \mathrm{~mm} \mathrm{NaCl}, 1 \mathrm{~mm}$ EDTA, $0.5 \%$ NP- $40,0.5 \%$ deoxycholate, $0.5 \%$ SDS, $0.5 \%$ aprotinin, and $0.2 \mathrm{mM}$ PMSF), centrifuged briefly, and the supernatant reimmunoprecipitated with anti-Mnt or anti-Myc serum. HS immunoprecipitations and washing conditions were carried out as described previously (Blackwood et al. 1992b). 


\section{EMSAS}

EMSAs were performed in $20 \mathrm{~mm}$ HEPES ( $\mathrm{pH} 7.5), 100 \mathrm{~mm} \mathrm{KCl}$, $10 \mathrm{mM} \mathrm{MgCl}_{2}, 5 \mathrm{mM} \mathrm{DTT}, 0.2 \% \mathrm{NP}-40,0.5 \mathrm{mg} / \mathrm{ml}$ bovine serum albumin, and $0.5 \mathrm{ng}{ }^{32} \mathrm{P}$-radiolabeled $\mathrm{CM} 1$ probe (CCCCCACCACGTGGTGCCTGA) in a total volume of $20 \mu \mathrm{l}$ for $15 \mathrm{~min}$ at room temperature. Protein-DNA complexes were resolved on $4.5 \%$ HEPES ( $25 \mathrm{~mm}$ ) polyacrylamide gels. In Figure 3A Max, purified from baculovirus (Ayer et al. 1993), and GSTMnt were used at a concentration of $\sim 10 \mathrm{ng} /$ reaction. To test for specificity, $1 \mu \mathrm{l}$ of Mnt or Max antiserum was included in the reactions. In Figure 3B, Max, GST-Mnt, and GST-Myc (C-176, the 176 carboxy-terminal amino acids of $\mathrm{c}-\mathrm{Myc}_{\text {; }}$ Blackwood and Eisenman 1991) were used at $\sim 5 \mathrm{ng}$ and in titrations at concentrations beginning at $2 \mathrm{ng}$ and increasing in threefold increments.

\section{Luciferase assays}

Human 293 cells were transfected with pSP expression plasmids together with $1 \mu \mathrm{g}$ luciferase reporter plasmid and $0.5 \mu \mathrm{g}$ of the $\beta$-galactosidase expression vector pCMV $\beta G A L$. Transfections were performed either in duplicate or triplicate and luciferase activity was normalized to $\beta$-galactosidase activity. To generate the reporter construct pGL2M4, a fourfold reiteration of the sequence CACGTG was introduced into the $S \mathrm{maI}$ site of pGL2 (Promega).

\section{Transformation assays}

Rat embryo fibroblasts were prepared and transfections performed essentially as described previously (Hurlin et al. 1995b) except transfected cells were not passaged following transfec-

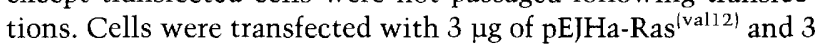
$\mu \mathrm{g}$ pLTR-Tc-Myc (Mäkelä et al. 1992) or together with $3 \mu \mathrm{g}$ of pRCMnt, pRCMnt $\Delta$ NT16, or pRCMad4. For other combinations and when individual plasmids were transfected, $3 \mu \mathrm{g}$ of each plasmid was used. Empty pRC vector was added in order to maintain equal amounts of transfected plasmids. Transformation assays using NIH-3T3 cells were performed the same as REFs. Cells were fed every 2 days with medium containing $5 \%$ fetal calf serum and cells stained with methylene blue and foci counted 2 weeks following transfection.

\section{Transgenic mice}

The plasmid pBAPmnt was constructed by inserting the 4.565 $\mathrm{kb}$ mnt cDNA (HindIII-BamHI fragment) into HindIII-BamHIdigested pBAP plasmid [a gift of William L. Perry III and Nancy Jenkins, National Institutes of Health (NIH), Bethesda, MD] such that the human $\beta$-Actin promoter drives expression of mnt. Expression of Mnt by this construct was first confirmed in transfected cells. The construct was linearized with Clal and microinjected into pronuclei (Hogan et al. 1994). DNA was isolated from tails clips of newborn pups ( 1 week old) or from the yolk sacs of embryos. Genotyping was performed by Southern blotting and/or PCR (yolk sac DNA). PCR primers used for pBAPmnt genotyping were 5'pBAP specific oligo: ATTCTCGCAGGATCAGTCG and $3^{\prime} \mathrm{mnt}$ specific oligo: CACTGCCTTCTTCCTTCCTTC. As a positive control for PCR genotyping $\beta T S H$ gene primers $\left(5^{\prime}\right.$ : TCCTCAAAGATGCTCATTAG, 3': GTAACTCACTCATGCAAAGT) were used. Embryos were fixed overnight in $4 \%$ paraformaldehyde then dehydrated in successive incubations in $30 \%, 50 \%$, and $70 \%$ ethanol and stored in $70 \%$ ethanol.

\section{Acknowledgments}

We thank Pei-Feng Cheng for expert technical assistance, $\mathrm{K}$. Foley and Y. Shiio for critical review of the manuscript, and members of the Eisenman lab for encouragement. We also gratefully acknowledge K. Lee for generating transgenic mice, P. Soriano for helpful discussions, $\mathrm{S}$. Hollenberg for providing materials for the yeast two-hybrid screen, $M$. Emerman for reagents, W.L. Perry and N. Jenkins for the $\beta$-actin promoter, and A. Ballabio, D.H. Ledbetter, G. Meroni, and R. Carrozzo for communicating unpublished results. P.J.H. was supported by a NIH fellowship during the initial phases of this work. This work was supported by grants from the American Cancer Society (NP-913) and from the National Cancer Institute, NIH (RO1CA20525) to R.N.E.

The publication costs of this article were defrayed in part by payment of page charges. This article must therefore be hereby marked "advertisement" in accordance with 18 USC section 1734 solely to indicate this fact.

\section{References}

Amati, B. and H. Land. 1994. Myc-Max-Mad: A transcription factor network controlling cell cycle progression, differentiation and death. Current Opin. Genet. Dev. 4: 102-108.

Amati, B., S. Dalton, M.W. Brooks, T.D. Littlewood, G.I. Evan, and H. Land. 1992. Transcriptional activation by the human $\mathrm{c}-\mathrm{Myc}$ protein in yeast requires interaction with $\mathrm{Max} . \mathrm{Na}$ ture 359: 423-426.

Amati, B., M.W. Brooks, N. Levy, T.D. Littlewood, G.I. Evan, and H. Land. 1993a. Oncogenic activity of the c-Myc protein requires dimerization with Max. Cell 72: 233-245.

Amati, B., T.D. Littlewood, G.I. Evan, and H. Land. 1993b. The c-Myc protein induces cell cycle progression and apoptosis through dimerization with Max. EMBO I. 12: 5083-5087.

Amin, C., A.J. Wagner, and N. Hay. 1993. Sequence-specific transcriptional activation by Myc and repression by Max. Mol. Cell. Biol. 13: 383-390.

Armelin, H.A., M.C.S. Armelin, K. Kelly, T. Stewart, P. Leder, B.H. Cochran, and C.D. Stiles. 1984. Functional role for cmyc in mitogenic response to platelet-derived growth factor. Nature 310: 655-660.

Askew, D.S., R.A. Ashmun, B.C. Simmons, and J.L. Cleveland. 1991. Constitutive c-myc expression in an IL-3-dependent myeloid cell line suppresses cell cycle arrest and accelerates apoptosis.Oncogene 6:1915-1922.

Ayer, D.E. and R.N. Eisenman. 1993. A switch from Myc:Max to Mad:Max heterocomplexes accompanies monocyte $/ \mathrm{mac}$ rophage differentiation. Genes \& Dev. 7: 2110-2119.

Ayer, D.E., L. Kretzner, and R.N. Eisenman. 1993. Mad: A heterodimeric partner for Max that antagonizes Myc transcriptional activity. Cell 72: 211-222.

Ayer, D.E., Q.A. Lawrence, and R.N. Eisenman. 1995. Mad-Max transcriptional repression is mediated by ternary complex formation with mammalian homologs of the yeast repressor Sin3. Cell 80: 767-776.

Ayer, D.E., C.D. Laherty, Q.A. Lawrence, A.P. Armstrong, and R.N. Eisenman. 1996. Mad proteins contain a dominant transcription repression domain. Mol. Cell. Biol. 16: 5772-5781.

Bello-Fernandez, C., G. Packham, and J.L. Cleveland. 1993. The ornithine decarboxylase gene is a transcriptional target of c-myc. Proc. Natl. Acad. Sci. 90: 7804-7808.

Berberich, S., N. Hyde-DeRuyscher, P. Espenshade, and M. Cole. 1992. Max encodes a sequence-specific DNA binding protein and is not regulated by serum growth factors. Oncogene 7: 775-779. 
Blackwell, T.K., L. Kretzner, E.M. Blackwood, R.N. Eisenman, and H. Weintraub. 1990. Sequence-specific DNA-binding by the c-Myc protein. Science 250: 1149-1151.

Blackwood, E.M. and R.N. Eisenman. 1991. Max: A helix-loophelix zipper protein that forms a sequence-specific DNAbinding complex with Myc. Science 251: 1211-1217.

Blackwood, E.M., L. Kretzner, and R.N. Eisenman. 1992a. Myc and Max function as a nucleoprotein complex. Curr. Opin. Genet. Dev. 2: 227-235.

Blackwood, E.M., B. Lüscher, and R.N. Eisenman. 1992b. Myc and Max associate in vivo. Genes \& Dev. 6: 71-80.

Campisi, J., H.E. Gray, A.B. Pardee, M. Dean, and G. Sonenshein. 1984. Cell cycle control of c-myc but not c-rasis lost following chemical transformation. Cell 36: 241-247.

Charron, J., B.A. Malynn, P. Fisher, V. Stewart, L. Jeanotte, S.P. Goff, E.J. Robertson, and F.W. Alt. 1992. Embryonic lethality in mice homozygous for a targeted disruption of the N-myc gene. Genes \& Dev. 6: 2248-2257.

Chen, J.T., L.R. Willinghan, R.L. Margraf, N. Schrieber-Agus, R.A. DePinho, and P.D. Nisen. 1995. Effects of the MYC oncogene antagonist, MAD, on proliferation, cell cycling and the malignant phenotype. Nature Med. 1: 638-643.

Coppola, J.A. and M.D. Cole. 1986. Constitutive c-myc expression blocks mouse erythroleukemia cell differentiation but not commitment. Nature 320: 760-763.

Cory, S. and J. Adams. 1988. Transgenic mice and oncogenesis. Annu. Rev. Immunol. 6: 25-48.

Crouch, D.H., F. Fisher, W. Clark, P. Jayaraman, C.R. Goding, and D.A.F. Gillespie. 1993. Gene-regulatory properties of Myc helix-loop-helix/leucine zipper mutants: Max-dependent DNA binding and transcriptional activation in yeast correlates with transforming capacity. Oncogene 8: 18491855.

Davis, A.C., M. Wims, G.D. Spotts, S.R. Hann, and A. Bradley. 1993. A null c-myc mutation causes lethality before 10.5 days of gestation in homozygous and reduced fertility in heterozygous female mice. Genes \& Dev. 7: 671-682.

DePinho, R.A., N. Schreiber-Agus, and F.W. Alt. 1991. myc family oncogenes in the development of normal and neoplastic cells. Adv. Cancer Res. 57: 1-46.

Desbarats, L., S. Gaubatz, and M. Eilers. 1996. Discrimination between different E-box-binding proteins at an endogenous target gene of c-myc. Genes \& Dev. 10: 447-460.

Downs, K.M., G.R. Martin, and J.M. Bishop. 1989. Contrasting patterns of myc and $\mathrm{N}$-myc expression during gastrulation of the mouse embryo. Genes \& Dev. 3: 860-869.

Evan, G.I., A.H. Wyllie, C.S. Gilbert, T.D. Littlewood, H. Land, M. Brooks, C.M. Waters, L.Z. Penn, and D.C. Hancock. 1992. Induction of apoptosis in fibroblasts by c-myc protein. Cell 69: 1-20.

Ferré-D'Amaré, A.R., G.C. Prendergast, E.B. Ziff, and S.K. Burley. 1993. Recognition of Max by its cognate DNA through a dimeric b/HLH/Z domain. Nature 363: 38-46.

Galaktionov, K., X. Chen, and D. Beach. 1996. Cdc25 cell-cycle phosphatase as a target of c-myc. Nature 382: 511-517.

Gaubatz, S., A. Imhof, R. Dosch, O. Werner, P. Mitchell, R. Buettner, and M. Eilers. 1995. Transcription activation by Myc is under negative control by the transcription factor AP-2. EMBO f. 14: 1508-1519.

Grandori, C., J. Mac, F. Siebelt, D.E. Ayer, and R.N. Eisenman. 1996. Myc-Max heterodimers activate a DEAD box gene and interact with multiple E box-related sites in vivo. EMBO J. 15: 4344-4357.

Gu, W., K. Cechova, V. Tassi, and R. Dalla-Favera. 1993. Opposite regulation of gene transcription by c-Myc and Max. Proc. Natl. Acad. Sci. 90: 2935-2939.
Hann, S.R. and R.N. Eisenman. 1984. Protein encoded by the human c-myc oncogene: Differential expression in neoplastic cells. Mol. Cell. Biol. 4: 2486-2497.

Harper, S.E., Y. Qiu, and P.A. Sharp. 1996. Sin3 corepressor function in Myc-induced transcription and transformation. Proc. Natl. Acad. Sci. 93: 8536-8540.

Henikoff, S. 1994. Unidirectional digestion with exonuclease III creates targeted breakpoints for DNA sequencing. Gene 28: $351-359$.

Henriksson, M. and B. Luscher. 1996. Proteins of the Myc network: Essential regulators of cell growth and differentiation. Adv. Cancer Res. 68: 109-182.

Hogan, B., R. Beddington, F. Constantini, and E. Lacy. 1994. Manipulating the mouse embryo. Cold Spring Harbor Labortory Press, Cold Spring Harbor, NY.

Hollenberg, S.M., R. Sternglanz, P.F. Cheng, and H. Weintraub. 1995. Identification of a new family of tissue-specific helixloop-helix proteins with a two-hybrid system. Mol. Cell. Biol. 15: 3813-3822.

Hurlin, P.J., D.A. Ayer, C. Grandori, and R.E. Eisenman. 1994. The Max transcription network: Involvement of Mad in differentiation and an approach to identification of target genes. Cold Spring Harbor Symp. Quant. Biol. 59: 109-116.

Hurlin, P.J., K.P. Foley, D.E. Ayer, R.N. Eisenman, D. Hanahan, and J.M. Arbeit. 1995a. Regulation of Myc and Mad during epidermal differentiation and HPV-associated tumorigenesis. Oncogene 11: 2487-2501.

Hurlin, P.J., C. Quéva, P.J. Koskinen, E. Steingrímsson, D.E. Ayer, N.G. Copeland, N.A. Jenkins, and R.N. Eisenman. 1995b. Mad3 and Mad4: Novel Max-interacting transcriptional repressors that suppress c-Myc-dependent transformation and are expressed during neural and epidermal differentiation. EMBO I. 14: 5646-5659.

Johnson, A.D. 1995. The price of repression. Cell 81: 655-658. Kastan, M.M., D.E. Ayer, and D.J. Stillman. 1996. SIN3-dependent transcriptional repression by interaction with the Madl DNA-binding protein. Mol. Cell. Biol. 16: 4215-4221.

Kato, G., J. Barrett, J.M. Villa-Garcia, and C.V. Dang. 1990. An amino-terminal c-myc domain required for neoplastic transformation activates transcription. Mol. Cell. Biol. 10: 5914 5920.

Kelly, K., B.H. Cochran, C.D. Stiles, and P. Leder. 1983. Cellspecific regulation of the c-myc gene by lymphocyte mitogens and platelet-derived growth factor. Cell 35: 603-610.

Koskinen, P.J., D.G. Ayer, and R.E. Eisenman. 1995. Repression of Myc-Ras cotransformation by Mad is mediated by multiple protein-protein interactions. Cell Growth Differ. 6: 623-629.

Kretzner, L., E.M. Blackwood, and R.N. Eisenman. 1992. The Myc and Max proteins possess distinct transcriptional activities. Nature 359: 426-429.

Lahoz, E.G., L. Xu, N. Schreiber-Agus, and R.A. DePinho. 1994. Suppression of Myc, but not E1a transformation activity by Max-associated proteins, Mad and Mxil. Proc. Natl. Acad. Sci. 91: 5503-5507.

Land, H., L.F. Parada, and R.A. Weinberg. 1983. Tumorigenic conversion of primary embryo fibroblasts requires at least two cooperating oncogenes. Nature 304: 596-601.

Li, L.H., D. MacGregor, C. Nerlov, G. Prendergast, and E.B. Ziff. 1994. c-Myc represses transcription in vivo by a novel mechanism dependent on the initiator element and Myc box II. EMBO I. 13: 4070-4079.

Litofsky, N.S., D. Hinton, and C. Raffel. 1994. The lack of a role for p53 in astrocytomas in pediatric patients. Neurosurgery 34: $967-972$.

Littlewood, T.D., B. Amati, H. Land, and G.I. Evan. 1992. Max 


\section{Hurlin et al.}

and C-Myc/Max DNA-binding activities in cell extracts. Oncogene 7: 1783-1792.

Lüscher, B. and R.E. Eisenman. 1990. New light on Myc and Myb. Part I. Myc. Genes \& Dev. 4: 2025-2035.

Mäkelä, T.P., P.J. Koskinen, I. Västrik, and K. Alitalo. 1992. Alternative forms of Max as enhancers or suppressors of Myc-Ras cotransformation. Science 256: 373-377.

Marcu, K.B., S.A. Bossone, and A.J. Patel. 1992. myc function and regulation. Annu. Rev. Biochem. 61: 809-860.

Moens, C.B., A.B. Auerbach, R.A. Conlon, A.L. Joyner, and J. Rossant. 1992. A targeted mutation reveals a role for N-myc in branching morphogenesis in the embryonic mouse lung. Genes \& Dev. 6: 691-704.

Moens, C.B., B.R. Stanton, L.F. Parada, and J. Rossant. 1993. Defects in heart and lung development in compound heterozygotes for two different targeted mutations at the $\mathrm{N}$-myc locus. Development 119: 485-499.

Mukherjee, B., S.D. Morgenbesser, and R.A. DePinho. 1992. Myc family oncoproteins function through a common pathway to transform cells in culture: Cross-inteference by Max and trans-acting dominant mutants. Genes \& Dev. 7: 2110 2119.

Packham, G. and J.L. Cleveland. 1994. Ornithine decarboxylase is a mediator of c-Myc-induced apoptosis. Mol. Cell. Biol. 14: $5741-5747$.

Phillips, N.J., M.R. Ziegler, D.M. Radford, K.L. Fair, T. Steinbrueck, F.P. Xynos, and H. Donis-Keller. 1996. Allelic deletion on chromosome $17 \mathrm{p} 13.3$ in early ovarian cancer. Cancer Res. 56: 606-611.

Prendergast, G.C., D. Lawe, and E.B. Ziff. 1991. Association of Myn, the murine homolog of Max, with c-Myc stimulates methylation-sensitive DNA binding and Ras cotransformation. Cell 65: 395-407.

Roussel, M.F., R.A. Ashmun, C.J. Sherr, R.N. Eisenman, and D.E. Ayer. 1996. Inhibition of cell proliferation by the Mad1 transcriptional repressor. Mol. Cell. Biol. 16: 2796-2801.

Roy, A.L., T. Gutjahr, C. Carruthers, and R.G. Roeder. 1993. Direct role for Myc in transcription initiation mediated by interactions with TFII-I. Nature 365: 359-361.

Sawai, S., A. Shimono, Y. Wakamatsu, C. Palmes, K. Hanaoka, and H. Kondoh. 1993. Defects of embryonic organogenesis resulting from targeted disruption of the N-myc gene in the mouse. Development 117: 1445-1455.

Schmid, P., W.A. Schultz, and H. Hameister. 1989. Dynamic expression of the myc proto-oncogene in mid-gestation mouse embryos. Science 243: 226-229.

Schreiber-Agus, N., L. Chin, K. Chen, R. Torres, G. Rao, P. Guida, A.I. Skoultchi, and R. DePinho. 1995. An amino-terminal domain of Mxil mediates anti-Myc oncogenic activity and interacts with a homolog of the yeast transcriptional repressor SIN3. Cell 80: 777-786.

Spencer, C.A. and M. Groudine. 1991. Control of c-Myc regulation in normal and neoplastic cells. Adv. Cancer Res. 56: $1-48$.

Stanton, B.R., A.S. Perkins, L. Tessarollo, D.A. Sassoon, and L.F. Parada. 1992. Loss of N-myc function results in embryonic lethality and failure of the epithelial component of the embryo. Genes \& Dev. 6: 2235-2247.

Västrik, I., A. Kaipainern, T.-L. Penttila, A. Lymboussakis, R. Alital, M. Parvinen, and K. Alitalo. 1995. Expression of the mad gene during cell differentiation in vivo and its inhibition of cell growth in vitro. J. Cell Biol. 128: 1197-1208.

Vojtek, A.B., S.M. Hollenberg, and J.A. Cooper. 1993. Mammalian Ras interacts directly with the serine/threonine kinase Raf. Cell 74: 205-214.

Wagner, A.J., C. Meyers, L.A. Laimins, and N. Hay. 1993. c-Myc induces the expression and activity of ornithine decarboxylase. Cell Growth Differ. 4: 879-883.

Wilkie, T.M., R.L. Brinster, and R.D. Palmiter. 1986. Germline and somatic mosaicism in transgenic mice. Dev. Biol. 118: $9-18$.

Zervos, A.S., J. Gyuris, and R. Brent. 1993. Mxil, a protein that specifically interacts with Max to bind Myc-Max recognition sites. Cell 72: 223-232. 


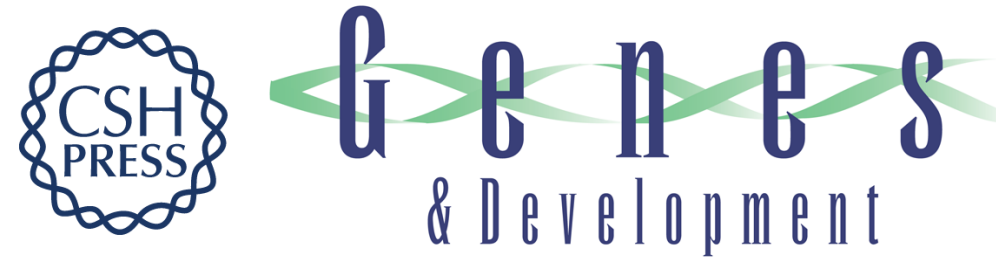

\section{Mnt, a novel Max-interacting protein is coexpressed with Myc in proliferating cells and mediates repression at Myc binding sites.}

P J Hurlin, C Quéva and R N Eisenman

Genes Dev. 1997, 11:

Access the most recent version at doi:10.1101/gad.11.1.44

References This article cites 72 articles, 31 of which can be accessed free at:

http://genesdev.cshlp.org/content/11/1/44.full.html\#ref-list-1

License

Email Alerting

Service

Receive free email alerts when new articles cite this article - sign up in the box at the top right corner of the article or click here.

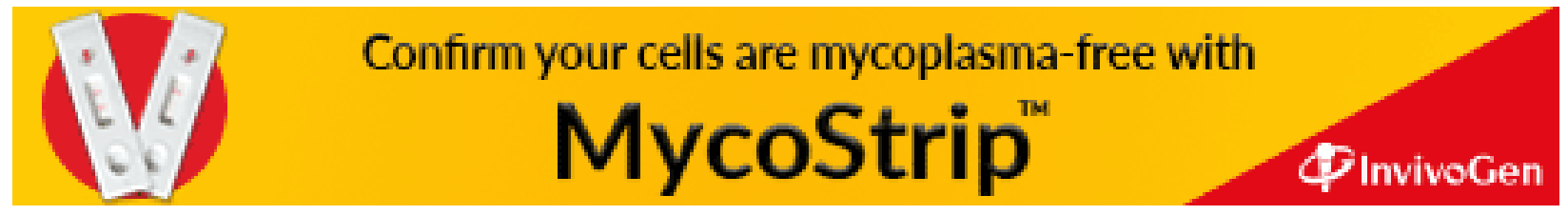

